\title{
FOR LOVE ALONE
}

\author{
Jeannette Ehlers
}

FOR LOVE ALONE is a 6 hours performative intervention, originally titled Into the Dark, created for Culture Night at the Royal Cast Collection/West Indian Warehouse in Copenhagen, 12 October 2018.

Accompanied by a soundtrack of the monologue Queen Mary Spirit, written by novelist and poet Tiphanie Yanique from the US Virgin Islands, two groups of four black women occupy the space of the old Warehouse and act as living sculptures, confronting our colonial history and coloniality with their mere presence. The number four is a tribute to the four rebel Queens who led the Fireburn: Queen Mary, Queen Susanna, Queen Agnes and Queen Mathilda.

The monologue looks into Queen Mary's motivations for the Fireburn labour revolt on St. Croix in 1878, blending reflections on motherhood, queendom and resistance against coloniality. The eight women change position as well as formations of the chairs each time the monologue is completed.*

The performance invites a dialogue with the public sculpture I Am Queen Mary, co-created by La Vaughn Belle and Jeannette Ehlers, which is placed just outside the Warehouse.

*Performed by Nina Cramer, Aiyun Nin, Elsie Siyum, Mary Tesfay, Natalia Medina, Winnie Seifert-Nketia, Zozo Mposula and Sara Toure. 


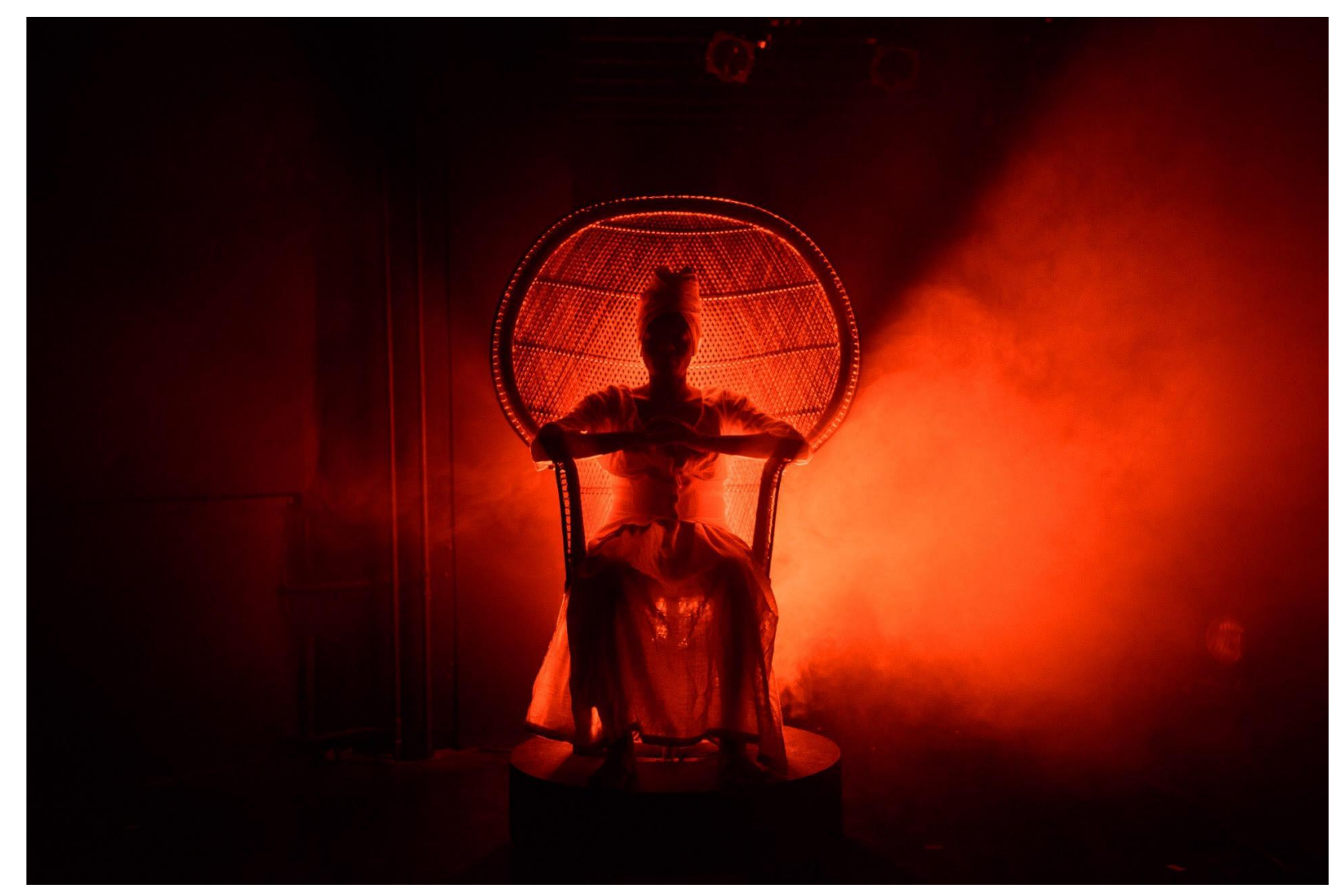

Into the Dark (2018), Jeannette Ehlers. Photograph by Søren Meisner.

Click here to watch an excerpt of the performance. 

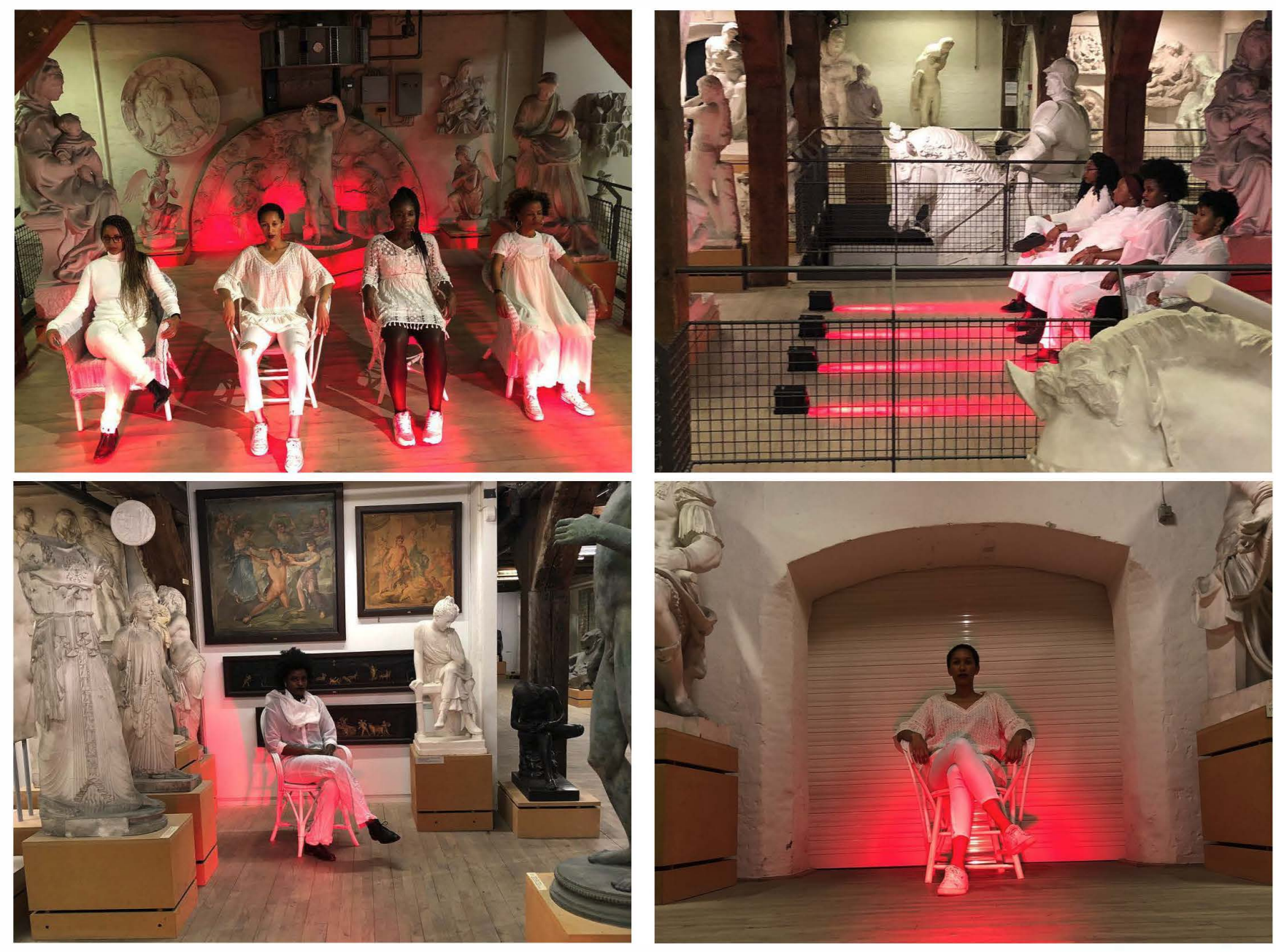
(This is Tiphanie Yanique. I am reading my monologue, Queen Mary Spirit, written for Jeanette Ehlers' Into the Dark.)

Tiphanie Yanique

Queen Mary Spirit)

I is Mary of Frederiksted St. Croix, in the Danish Virgin Islands. Is 1878, and people still believe in God. We in the West Indies been free from slavery some thirty years. So they say. But it don't feel so. We work like slaves. We hated like slaves. I don't lie. People still believe in God, but not many of we believe in love. But I is Mary of Frederiksted. I believe in God and I still believe in love.

Is love, I love my sons. I love the skin on Palés arms. He the darker one, black like pitch, and smooth as the sea. I love the rough skin tips of Horay's fingers, for he my worrying child and he always biting. But I know that worrying is loving, so I love them finger of Horay's. I love the way my boys say "yes, mama" to me in private, even though now they is big man, each with a woman or two of they own. I love how if I just give them the eye, they stop their stupidness and come to my side. That is a mama's earned justice.

I loved them boys from when they broke out of me. One by one. Not a year a part. Each of them, their big heads opening me, stretching my tun tun, beyond its limits. I loved my boys the most then. How they could stretch skin to make way for their own skin. God make mothers to bare just so. And love just so. To the breaking.

Which is how come is we woman, we mothers, must be the ones to bare and break this boy-land we love. Saint Croix. Is we-self we breaking. But is Saint Croix-self we borning. We do so by burning. We burn it all down, so it go. We do it for we. The Danish man-them ain paying we enough. They ain respecting the work it is we doing. I seeing them with their nice shoe and I seeing my Pale and Horay with no shoes at all. I know God, which means I know what is just and right and good and love. And I know this ain love these plantation owners showing we with their pittle pay. I know this ain just and right and goodso it can't be love. Love is what I know. To the breaking and the burning, I know it.

The Fireburn. That is what it getting call now. What we West Indians calling it. You, maybe, calling it a rebellion. You, maybe, calling it a riot. I suppose that depend on how you understand love, and who it is you choosing to shine that love-light on. Because I here with you. In Denmark. I here in the jail for being a queen. Not like what you have. Our island queens don't sit in court yard castle. Our queen does cut cane. Our queens ain born to queendom. They chosen. And not by God, but by the bodies God make. I chose by the people. The people chose me and the others. Choose me to lead them. And so it go. We women, we lead. We lead the Fireburn. We lead.

I only accept being a queen because of Palé and Horay. Understand, my boys ain babies no more. They can't move skin, they can't re adjust muscle to their own music. Nobody going to open for them, bare down for them. Not even the women that loving them. No woman but me. That's mother-love.

And is so bad I love my boy's skin. I loved that skin even when I used to take the whip to it. When I took a cane to it. When I took my own hard hands to it. I loved their skin even when they was young boys and I had to bruise their bums with the force of my own body. I loved the skin on the back of their 
legs. Even when I scorched it open. Had to. Because I loved them like I loved them when they was born.

I will, I will, I will beat them to save them. Because what is skin? It's their mother scunting lives I saving. I would slice their skin open. I would beat them beyond blackness. And is just so I doing God's work. A queen's work, you hear? Is me beat them so that the jumbie white man who have we cutting cane don't beat them. When he beat them is hate for their skin and want for the money their labor bring. Is that same hate and greed that going kill my boys if I don't guard and guide. When I beat them is love, is warning, is to keep them alive.

See, I can't let Palé and Horay carry those bodies I love, their bodies that come from my body, into no foolish danger. Because in 1878, in the Danish West Indians, if you a black boy, any danger means death. My boys sick with fever and can't cut cane enough? The greed jumbie white man going to beat them. They eat too much rations? The greed jumbie going to beat them. They want court a pretty woman who pale in color? The hate jumbie white man going to flay their skin. They want to put a way a little money for their children-them they going to make? The hate jumbie going to call them thief. Get them beat and burned to jail. Jumbie white man. I don't know if they have another kind. Some say they have nice white people up here in Denmark. Like they must be send the jumbie hate ones, the greed ones, alone down to we? But I here in Denmark now... and they all seeming the same. We up here. Me and the other queens of the fireburn, the queens of Frederiksted. Our brown skinned bodies up here in this pale place, even the Queen up here so pale. I can't see what work she ever do in she life. How the people could follow she? I suppose her body don't need to work, I suppose her boys's bodies don't need no protection.

That is why I need Palé and Horay skin sweet with fear. Fear keeps their blood inside their bodies. So I take a little blood. A toonchy thing. I take a little blood from my boys for my boys. So they won't have to chuck all the blood for the white man. Their blood is on my knuckles, so their blood ain in the street. That is love. Beat the boy's body, to save the boy's body. That's how much I love my boys. Any fool could see God on my side here.

I gave Palé and Horay each a knife. Because they have to know to protect they selves, now that they is man. How to protect they women and the children they going to make. This is a corporal life we here living on earth. And just as my boys learn from me how to take a beating, how to be afraid--they must learn themselves how to give a lashing, how to make another body 'fraid. They going learn that like any man does learn or not learn-by living or dying. But they also gonna learn from me.

Now the Danish men say I here in this jail for burning the land. But the mothers here in this Denmark? They say I hear for beating my boys. I confess to both. But what kind of ting it is, what kind of ignorance it take for these men and these mothers to not see me as they own? I labour hard as any Danish man. I love my children as hard as any Danish mother. But is a different world they in. Is which land and which bodies - that is the difference. These Danes, you Danes, you have a land here where your man body could work and receive a decent pay. A land where the mothers can love their children bodies gentlelike and trust that gentle love alone will protect their children. Their queen make sure they have that here. She my queen, too, I gather. But my body back in St. Croix ain receiving the same pay, and my boy's bodies ain receiving the same protection.

Is so, I suppose, we come to be our own Queens. 
Yes, we burn. We scorch it. Make the skin-land go red and then ash. Strip it to save it. Now how can it be that that is what these man and mothers have me now lock up in Copenhagen for? Saving my boys. Saving my islands. Any parent knows what I'm saying. Any parent knows. Father God knows and understands.

When fire burn Frederiksted is not that we was only lashing the white jumbie man produce. I ain no fool. We licking we, too. We sacrificing by destroying. Because this St. Croix, this Danish West Indies, is we. My land is my skin, the cane my own hands cut is my hands. I know I stripping my own skin when I set the flame. Just like I strip Horay skin when I catch him kissing that white girl. Have to teach him. Have to make sure he have the appropriate fear, a good healthy dosing of fraid. Maybe too much, with them worry fingers of his. But is okay. Because he have Palé and Palé won't leave Horay stupid.

Thank God I make two boys and not one alone. They can love each other even if I gone and dead up in this white jumbie place beyond God back.

I here in Denmark. But I am Mary of Frederiksted. I am Queen Mary. Queen Mary of the Fireburn. I know God and I know God is love. Is love I love these boys-so I beat them. Is love I love these islands so I burn them. That is self-sacrifice. That is parent love. Father God, who done send his most beloved son, in the path of nail and thorns, he know about that. He know why we Queen lead the burning down of every last plantation on St. Croix. Is for love. Is for love. Is for love alone. 

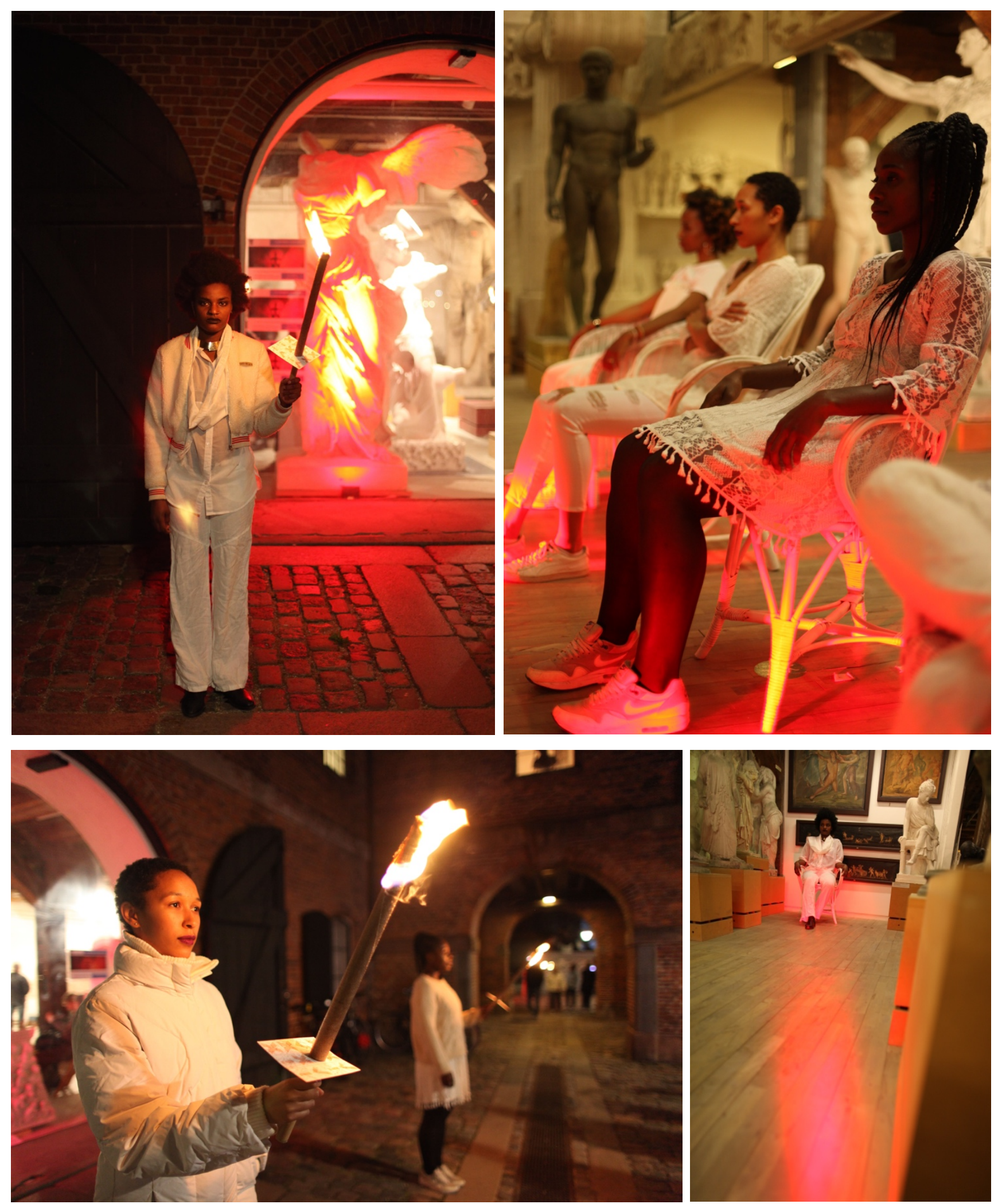
Jeannette Ehlers is a Copenhagen-based artist of Danish and Trinidadian descent whose practice takes shape experimentally across photography, video, installation, sculpture and performance. She graduated from The Royal Danish Academy of Fine Arts in 2006. Ehlers' work often makes use of selfrepresentation and image manipulation to bring about decolonial hauntings and disruptions. These manifestations attend to the material and affective afterlives of Denmark's colonial impact in the Caribbean and participation in the Transatlantic Slave Trade-realities that have all too often been rendered forgettable by dominant history-writing. In the words of author Lesley-Ann Brown, "Ehlers reminds all who participate in or gaze at her work that history is not in the past." Ehlers insists on the possibility for empowerment and healing in her art, honoring legacies of resistance in the African diaspora. She merges the historical, the collective and the rebellious with the familial, the bodily and the poetic.

On 31 March 2018 she unveiled I Am Queen Mary, a public sculpture project in collaboration with La Vaughn Belle, at the Royal Cast Collection/West Indian Warehouse in Copenhagen, Denmark.

Selected Exhibitions:

Maxim Gorki Theater, Berlin, DE * Ford Foundation Gallery, NYC,US * LACE, LA,US * SAVVY Contemporary Berlin, DE * The Finnish Museum of Photography, Helsinki, FI * Canton Gallery, Guangzhou, CN *, CareOf, Milan IT *, Frost Art Museum, Miami, US * CAMP, Copenhagen, DK*Chez Eva@Galleri Futura, Stockholm,S* Wallach Art Gallery, NYC,USA * AROS, Aarhus, DK * MOLAA, Los Angeles, USA * The Black Diamond, Copenhagen, Denmark * International Slavery Museum, Liverpool, UK* 21c Museum Hotels, Louisville, Kentucky, US * Reykjavik Art Museum, IS * Autograph ABP, Rivington Place, London,UK * UVP on Everson Museum of Art, Syracuse, USA * Brundyn+ gallery, Cape Town SA * Nikolaj Copenhagen Contemporary Art Center, Copenhagen, DK* LMAKprojects, NYC, USA * Dak'Art, Dakar, Senegal * Pérez Art Museum Miami, USA * Parisian Laundry, Montreal, Canada * Ballhaus Naunynstrasse, Berlin, Germany * Museo Del Barrio, New York, USA * https://www.jeannetteehlers.dk/ 